\title{
Revival of Oceanography in Germany
}

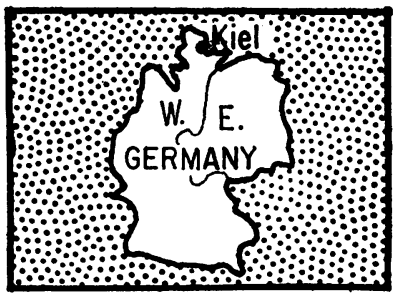

Kiel. In a program to revive Germany's important pre-World War II work in oceanography, German scientists are expanding academic centers for marine science, most notably in Kiel and Hamburg, and readying a large new ocean-going research ship for a voyage this fall to the Persian Gulf and the Indian Ocean. This will be part of the International Indian Ocean Expedition, in which Germany has a considerable role, as she had in oceanographic studies of the IGY.

The \$4-million research ship has been given the name Meteor, made notable in the 1920's when an earlier German ship Meteor made pioneering voyages to study the detailed physical characteristics of the Atlantic south of latitude $20^{\circ} \mathrm{N}$. After adjustments have been made in her equipment, following a shakedown cruise in the Bay of Biscay in the early fall, the new Meteor will sail for Aden, arriving about 1 December. The scientists aboard will survey the outflow of water from the Red Sea into the Arabian Sea and will study the currents along the coast of Somalia during the first part of the winter monsoon. This will be a followup of work done in the Indian Ocean in the summer of 1963 by the British research vessel Discovery and the American Atlantis II, of the Woods Hole Oceanographic Institution, and this past summer by the Discovery and the Argo, research vessel of the Scripps Institution of Oceanography. During the summer monsoon, when winds blow strongly from Africa toward India, large masses of surface water in the Indian Ocean flow away from the coasts of Somalia and southeast Arabia, causing an upwelling of cool, nutrient-laden water from below. The German oceanographers aboard the Meteor will follow up the summer surveys of these areas of high biological productivity made by the British and American vessels, studying the areas under the sharply altered conditions of the winter monsoon, when the winds blow off the Himalayas toward Africa.

In August 1965 the Meteor is sched- uled to go on its second cruise for basic research, as part of the program of the International Years of the Quiet Sun. It will be stationed in the Atlantic near the St. Paul rocks, close to the magnetic and geographic equators. An American vessel will be stationed at a "conjugate" geomagnetic point in the Pacific.

Unlike the recently constructed or adapted American oceanographic vessels, the Meteor will serve all branches of marine science instead of specializing in physical or biological studies. At this stage, the Germans agreed, they could afford only one major vessel equipped for basic research at sea. Unlike other German research ships, the Meteor is planned explicitly for basic research. The earlier Meteor (now the Soviet research vessel Equator) was originally built as a gunboat. Neither the new German fishery research vessel Walther Herwig, which studies the performance of various arrays of fishcatching gear, or the 1000-ton fishery research vessel Anton Dohrn, built in 1955 and used with the 800-ton Gauss for the multi-nation polar front survey south of Greenland during the IGY, was specifically designed for research in all branches of marine science.

The Meteor is 82 meters long and 13.5 meters across. Its maximum speed is 14 knots. The crew numbers 55 . Besides devices to cut down vibration and noise and a special window for observing cavitation effects from the propeller, the ship has special tanks in which water moves to offset rolling in rough seas. The ship's 12 laboratories have been placed close to the center of gravity. Because the section of the ship carrying the bridge is high and bears the weight of a stabilized platform for radio-meteorological instruments and a weather radar, the ship would roll in a side wind were it not for corrections provided by a bow propeller. This propeller can also be used for maneuvering and holding the ship steady for making precise measurements.

The Meteor carries a temperature- controlled aquarium, refrigerators for specimens (temperatures of $-4^{\circ}$ and $-30^{\circ} \mathrm{C}$ ), narrow-beam echo sounders, a helicopter hangar and landing deck, facilities for launching weather balloons, a gravity meter which operates while the ship is under way, a sediment echo-graph of the Edgerton "boomer" type, an A-frame for towing trawls, and cranes and long lines capable of lowering and raising geophysical devices, such as deep-sea corers, weighing up to 11 tons.

Fifty-four marine scientists will take part in the Meteor's Indian Ocean cruise; of these, 19 are from the University of Kiel's department of marine science and eight are from the department of geology and paleontology. Guenter Dietrich, head of the department of marine science, will be the scientific leader aboard the research vessel. Dietrich came to Kiel in 1959 from the German Hydrographic Institute in Hamburg. Kiel and Hamburg are the key points in the program for expanding oceanographic activities, proposed by the German Research Association in 1962 and implemented since that time. According to the arrangements for financing the Meteor, half its time, in future, will be planned by the German Research Association, half by the German Hydrographic Institute. In its second cruise for basic research, next August, the scientific work will be under the leadership of Walter Dieminger of the Max Planck Institute for Aeronomy, Lindau, and Karl Brocks of the Institute for Meteorology, University of Hamburg, with members of the German Hydrographic Institute participating.

\section{Kiel Scientists and the "Meteor" Cruise}

The Kiel scientists who will take part in the Indian Ocean cruise this fall, or have designed instruments for the voyage, have varied backgrounds and are engaged in many aspects of oceanography. Dietrich, born in Berlin in 1911, hardly ever saw the sea until he had completed doctoral studies in physics and mathematics at the Uni- 


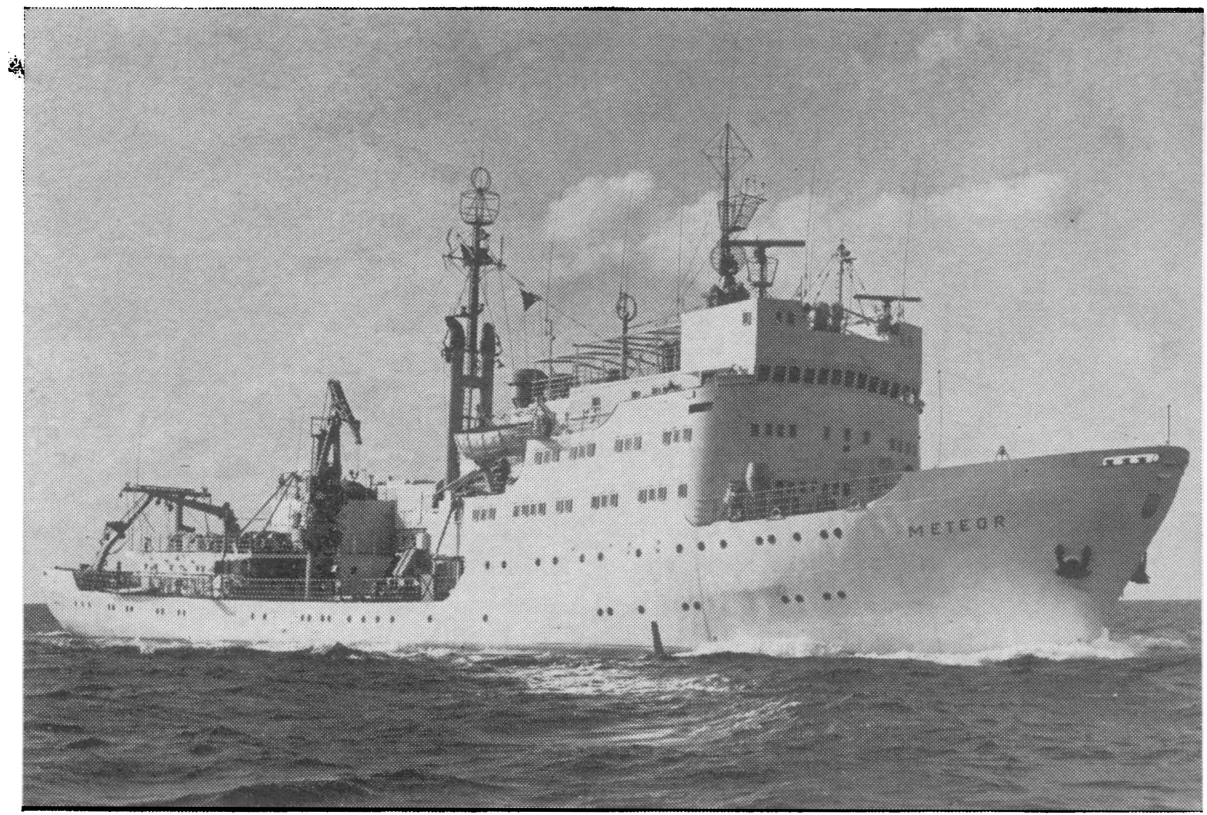

New German oceanographic vessel Meteor (2740 tons).

versity of Berlin. As a student, he had planned a teaching career, but to earn money he took a job drawing maps. The maps happened to be those for the volumes of reports on voyages of the first Meteor. And so, 2 days after he received his doctorate in 1935 , Dietrich boarded the Meteor, bound for waters south of Greenland. Later he went on Meteor voyages to the tropical Atlantic. Most of the data from these voyages disappeared from Berlin during World War II, but after the war Dietrich was able to retrieve from various hiding places the data for nine stations off West Africa. He joined the German Hydrographic Institute in 1949 and accompanied such expeditions as the IGY polar front survey, which he has since reviewed in a special volume on the IGY published by the National Academy of Sciences in 1964.

Also aboard the Meteor will be Gerald Siedler and Gunther Krause. In 1963, with Dietrich, Siedler described a new current-recording meter for anchoring in the open sea [Kiel. Meeresforsch. 19, 3 (1963)]. Siedler works with the "bathysonde" for recording temperature and salinity; the instrument is to be used on the Meteor cruise for measurements down to 2000 meters. The bathysonde [Deep Sea Research 10, 269 (1963); ibid., in press] was developed several years ago at the University of Kiel's Institute of Applied Physics. With Krause, Siedler developed an underwater winch system in which the sensors follow a special temperature or light intensity, or move up and down recording the layering of temperature. Krause announced in 1963 [Kiel. Meeresforsch. 19, 175 (1963)] the development of an instrument for measuring the optical properties of sea water at great depths. Through a single conductor cable 10 kilometers long Krause's instrument can receive power for its artificial light source and transducers and can transmit six different measurement values for the attenuation of light and its scattering by particles in the water. Three transducers in the instrument convert data on light intensity, temperature, and pressure into alternatingcurrent frequencies. In. 1963 Krause reported use of this instrument for continuous recordings of light transmission and temperature down to 1.5 kilometers.

Klaus Grasshoff, another Kiel scientist, reported in 1962 the development of an oxygensonde [Kiel. Meeresforsch. 18, 151 (1963)] which he used in the Baltic and North Atlantic for measuring vertical distribution of oxygen down to 600 meters. He hopes to reach 600 meters with this instrument at all the Meteor's hydrographic stations in the Indian Ocean.

Dietrich and Helmut Hunger reported, in 1962, development of a deep-sea television camera which could operate down to 2 kilometers [Deut. Hydrograph. Z. 15, 229 (1962)].

Peter Koske, who spent a year at Woods Hole recently, has built a meter for making continuous readings of the salinity of sea water. The instrument uses chloride ion concentration rather than conductivity as its yardstick. The device is much less affected by temperature than the conventional device based on conductivity, but it is less sensitive. Koske intends to use the instrument when the Meteor is in the Persian Gulf. Salinity in the Gulf varies sharply, from low salinity near the mouth of the Tigris-Euphrates river system to almost 40 parts per 1000 in backwaters of Oman.

On a recent Baltic cruise of the marine science department's cutter Hermann Wattenberg, led by Wolfgang Krauss and made in cooperation with countries of Scandinavia and the Soviet Union, Koske had a chance to test the new instrument closely. The Baltic is $\bullet$ much less saline than the open ocean salinity is 7 parts per 1000 , as against35 . It is also full of internal waves, and is highly stratified. Krauss has been occupied with these very complicated ${ }^{\circ}$ internal wave patterns since 1960 . $\mathrm{He}_{0}^{\text {bo }}$ recently spent 6 months at the Naval ${ }_{0}^{\circ}$ Electronics Laboratory in San Diego, where much attention is devoted to $\triangle$ internal waves. Investigations with echo sounders have revealed as many as half a dozen distinct "deep scattering layers" in shallow waters. In the open ocean such layers occur at much greater depth intervals and often can be attributed to dense plankton colonies moving toward the surface at night and sinking during the day. In the Baltic, however, work by Juergen Lenz of the $\mathbb{D}$ marine science department's plankton $\%$ study group proved that the layers could not be due to plankton. The most logical alternative, it was felt,, would be changes in water density, which would be marked by changes in temperature or salinity. Continuous measurement of temperature and salinity with Koske's instrument showed a strong correlation between the location of density changes and of the scattering layers which were showing up on the echo sounders.

Another Kiel scientist who will go to the Indian Ocean is Walter Dueing, who recently used current meters attached to special alloy masts (developed by Krauss), to measure the variation of currents leading into the bay of Naples-the current between the island of Ischia and the shore and that between Capri and the peninsula on which Sorrento and Amalfi lie. Dueing undertook the work partly because biologists visiting the marine zoological 
station at Naples did not have precise data on the currents in the bay of Naples, which affect plankton density. For over 7 months, Dueing made absolute measurements of current flow through the two straits and indirect measurements based on changes of potential along the telecommunications cables under the straits. The data indicated that the flow between Ischia and the mainland is about 7500 cubic meters a second, while that between Capri and the mainland is 40,000 cubic meters. (The flow of the Mississippi is about 17,000 cubic meters.) From current-direction data Dueing developed equations whereby the data could be correlated with wind data. The studies showed that the currents vary chiefly with onshore and offshore winds.

Krey, who heads the department of marine science's studies of plankton, is involved in many international projects. $\mathrm{He}$ is the coordinator of plankton studies for the International Indian Ocean Expedition, serves on the marine science panel of the proposed International Biological Program, and serves on a panel of the Scientific Committee on Oceanic Research. Through his coworkers at Kiel and colleagues abroad, Krey has, during the past 10 years, assembled plankton samples from the Baltic, the North and Arabian seas, the northern North Atlantic, the tropical Atlantic, and the Indian Ocean northwest of Australia. Berndt Zeitzschel and Wolfgang Hickel of Krey's group collected plankton samples aboard ships of the Guinea Trawling Survey in the summer and autumn of 1963 and again from January to May this year. Erik Hagmeier and Walter Nellen of Krey's group accompanied the first three expeditions of the International Cooperative Investigations of the Tropical Atlantic (ICITA), to collect plankton. Hagmeier also accompanied an expedition led by G. F. Humphrey of Australia. Nellen and two others of Krey's group, Lenz and Rolf Boje, will go to the Indian Ocean with the Meteor.

Krey's group has helped develop methods for analyzing samples in which the plankton weigh only 10 micrograms per liter of water. Since the IGY, plankton specialists have been using optical devices as indicators of likely places for plankton sampling. One of these has been a transparency meter developed by Joachim Joseph, formerly of the German Hydrographic Institute in Hamburg and now at the International Atomic Energy Agency's laboratory at
Monaco. Krey's group, using photomicrographs in a semiautomatic process, has been measuring the size of suspended particles ranging from 1.5 microns to 2 millimeters in diameter, and counting the number of living and dead organisms. The elaboration of these methods has allowed calculation of the quantity of very fine decomposed matter in sea-water samples. This detritus derives not only from creatures now living in the sea, Krey thinks, but also from the melting of icebergs. Investigations of detritus are important, Krey maintains, because it may turn out that this material is a major source of nutrients for marine bacteria.

Methods for detecting very faint traces of dissolved organic carbon, particulate carbon, chlorophyll, and particulate phosphorus are being developed for the Indian Ocean studies, Krey reports; some of these methods have been used in ICITA expeditions.

Plant physiologist Fritz Gessner joined the department of marine science 3 years ago, after 22 years as a professor at Munich. He has been an editor of the Handbuch der Biologie for the last 10 years, and co-editor of a journal of hydrobiology published in East Berlin. He has a special interest in marine algae and has been issuing a systematic work called Hydrobotanik. Volumes on energy problems and metabolism have appeared, and a third, on ecology, is in preparation.

One of Gessner's colleagues, Heinz Schwenke, is studying the geographic distribution of marine plants in the western Baltic. Another marine botanist is Reiner Simonsen, a student of marine diatoms, who recently spent a year at the Scripps Institution of Oceanography.

\section{History of Marine Research at Kiel}

The history of marine research at Kiel begins in the 1870's when Victor Hensen, who coined the term plankton, began teaching here. Hansen led a major plankton survey expedition aboard the German vessel National in 1889. By 1900 the Prussian marine research commission had established physical, chemical, and biological laboratories at Kiel, but teaching at the university was concentrated on zoology and physiology.

After World War I, marine studies continued modestly at Kiel, while Alfred Merz of the department of marine science at the University of Berlin led German oceanographers in the pioneer Meteor survey of the Atlantic. With the help of the German Navy and the

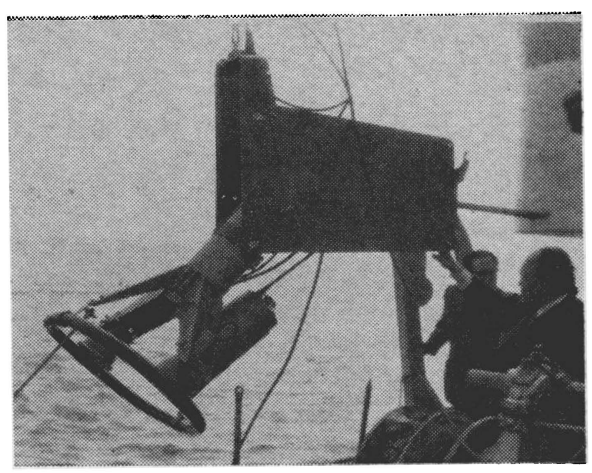

Eugen Seiboldt (right) and Guenther Dietrich (left) inspect deep sea TV equipment at Kiel.

Emergency Fund for German Science, the Meteor was sent to make 14 profiles, 300 kilometers apart, across the Atlantic. These ran from the antarctic ice pack, at $63^{\circ} \mathrm{S}$, to $20^{\circ} \mathrm{N}$. In $1937-38$, three more Meteor profiles carried the survey of water circulation, oceanatmosphere exchanges, chemical composition of sea water, plankton, sediments, and bottom topography in the Atlantic to $30^{\circ} \mathrm{N}$. Albert Defant of the Berlin oceanographic institute edited the Meteor findings, which were published in 30 volumes.

One of the veterans of the pioneer Meteor expeditions was Hermann Wattenberg, a marine chemist. In 1937 Wattenberg was named first director of the then new department of marine science at Kiel. He launched a formal program in physical oceanography at the university, but was killed by the World War II bombing which destroyed his institute building and 80 percent of the city.

At the end of the war the first steps of the revival of oceanography in Germany were almost immediate. Dietrich recalls, "When we were at the zero point of our existence in 1945, there was one commander who came as supervisor for oceanography from the British navy to our country. He did not come as a conqueror who drove the oceanographers in all directions. . . He gave them chances to work in Hamburg and Kiel. . . . [If oceanography revived in Germany] it was by his help. This is Dr. J. N. C. Carruthers ... of [the British] National Institute of Oceanography. ..."

After World War II, another veteran of the early Meteor expeditions, Georg Wuest, who had assisted Defant in editing the Meteor volumes, was named to head the department of marine science at $\mathrm{Kiel}$. Wuest, a specialist 
in ocean circulation who had traced the movement of oxygen-rich midAtlantic water down to the Antarctic, retired in 1959 and went immediately to the Lamont Geological Observatory, on a Ford Foundation grant. There, with the assistance of Arnold Gordon and support from the U.S. Atomic Energy Commission, he produced a detailed study of circulation and stratification in waters of the West Indies. Wuest modeled the study on his earlier work in the Mediterranean and the Atlantic. The first volume, accompanied by an atlas, was published in 1964. In a foreword, Maurice Ewing described Wuest's work as "the first comprehensive description of the water masses of the Antillean-Caribbean basins, their interaction with the atmosphere and circulation in their depths."

Since Dietrich succeeded Wuest as head of the department of marine science in 1959, the department has expanded from quarters in a converted private house into eight other buildings scattered throughout the town. Land has been acquired and money approved for construction of a single large building on the harbor front; this should be ready in about 3 years. The staff has increased from 14 to 87 . Of these, 57 are paid by the university and the others receive support from the German $\mathrm{Re}$ search Association and other sources.

Collaborating closely with the department of marine science are Karl Jung, a specialist in gravimetry who heads the department of geophysics at Kiel; Seibold, head of the geology department; and Werner Kroebel of the applied physics department.

\section{The Polar Front Survey}

German scientists made a considerable contribution to the oceanographic programs of the IGY. Typical of these programs was the polar front survey, reviewed by Dietrich in the National Academy of Sciences volumes on the IGY.

The survey covered the North Atlantic, northeast of a line from Newfoundland to the Azores and Morocco, as far north as the west coast of Greenland and Spitsbergen. Twenty-five research vessels from 11 nations, with 150 scientists aboard, followed assigned tracks during the late winter of 1958 and followed almost exactly the same tracks 6 months later, at the end of the summer. The tracks were planned to catch the changeable Gulf Stream at many points, and at two extreme seasons of the year. Of special interest was the interaction of the Gulf Stream, compressed into a narrow jet, with the polar currents south of Greenland, and over a point of about $52^{\circ} \mathrm{N}$, where the Mid-Atlantic Ridge suddenly changes direction. This polar survey was one of five synoptic marine programs of the IGY. The others were studies of deepsea circulation, long waves, mean sea level, and strong ocean currents.

The German contribution to evaluation of the findings has been large. G. Boehnecke and A. Bueckmann edited 18 papers by German participants aboard the Anton Dohrn and the Gauss which appeared in the Deutschen $\mathrm{Hy}$ drographischen Zeitung in 1959. In the same journal, in 1960, Dietrich reviewed polar front measurements of oxygen, temperature, and salinity. Joseph discussed current and temperature profiles, and in 1962 Ulrich described the echo soundings. Final publication of the survey data, including an atlas, has been turned over to a working group headed by Dietrich. Since 1961, all the observations from the survey's 2500 stations have been transferred to punched cards for an analysis which is being aided by the U.S. National Oceanographic Data Center in Washington.

Dietrich notes that the survey examined a number of important features of the North Atlantic.

1) The shelf-like rise between Greenland and Scotland, a flat region 200 to 400 meters below the surface. Deep channels across the rise at two pointsbetween Greenland and Iceland and between the Faroes and Scotland-allow the escape of very cold bottom water from the Norwegian Sea.

2) A rise in the continental shelf off Greenland and Labrador (the latter observed by Soviet oceanographers) just before the shelf begins its steep slope down into the abyssal plain. Dietrich feels these rises are terminal moraines deriving from Pleistocene glaciers.

3) The absence of the normal central rift valley at three northern crossprofiles of the Mid-Atlantic Ridge.
These profiles were made by the Anton Dohrn at $66^{\circ}, 65^{\circ}$, and $63^{\circ} \mathrm{N}$.

4) The apparent presence of deep channels across the Ridge around $52^{\circ} \mathrm{N}$, where the ridge course changes from NE-SW to NW-SE. The channel is inferred from the behavior of the Gulf Stream jet at this point.

5) A new seamount 20 nautical miles in diameter between Rockall and the Hebrides. This has since been named Anton Dohrn for the ship whose scientists explored the feature in detail. Recent German investigations with a narrow-beam echo sounder have revealed that there is a sharp depression at the foot of the seamount. The depression is the deepest feature of the area. Dietrich remarks that the seamount set in the middle of this depres- $-\frac{6}{}$ sion "gives the impression that a stop-त per had sunk back into a tough mass from which it had ascended." Dietrich speculates that other seamounts in the area are also "sinking faster than sedimentation can fill the depressions."

6) Cyclonic systems in the ocean, io sending up nutrients and bringing down oxygen-rich water.

Since the IGY, German oceanogra-. phers have taken part in such follow-up investigations as the five-nation, nineship study of the southward overflow of. water from the Norwegian Sea into the Atlantic abyssal plain between the Faroes and Iceland in 1960; a GermanIcelandic survey of redfish spawning grounds in the Irminger Sea in 1961; and a multi-national survey of the Irminger and Labrador seas, sponsored by the International Commission for the Northwest Atlantic Fisheries, in the spring and summer of 1963.

Anchored buoys in the 1960 overflow survey showed sharp variations over time. Dietrich feels that this finding is just one indication of the important role anchored buoys and other instruments to measure parameters in space and time will play in oceanography. He says: "We almost know the forces acting on the sea. We further know approximately the final state as expressed by the distribution of hydrographical factors. We are still missing deeper insights into the dynamical processes existing between the forces and the final state."

-Victor K. MCElHeNy 